\title{
普通ポルトランドセメント中の間隙相の初期水和に及ぼす 亜硝酸カルシウムの影響
}

\author{
大宅淳一 ${ }^{* 1}$ 新大軌 ${ }^{* 2}$ 原弘峻 ${ }^{* 3}$ 須藤裕司 ${ }^{* 4}$
}

\author{
*1 日本大学 理工学部 ( ₹ 274-8501 千葉県船橋市習志野台 7-24-1) \\ *2 島根大学 大学院総合理工学研究科 (T690-8504 島根県松江市西川津町 1060) \\ *3 九州大学 大学院総合理工学府 (T816-8580 福岡県春日市春日公園 6-1) \\ *4 日産化学工業株式会社 化学品事業部 ( T101-0054 東京都千代田区神田錦町 3-7-1)
}

\begin{abstract}
要旨：普通ポルトランドセメントの初期に扔ける水和反応におよぼす亜硝酸カルシウムの影響について検 討した。亜硝酸を添加した普通ポルトランドセメント試料では、水和 30 分、1 日、14 日に扔いて、エト リンガイト拉よび亜硝酸イオンを取り込んだ $\mathrm{AFm}$ 相の生成が確認された。また、水和 48 時間までの普 通ポルトランドセメントの積算発熱量は、亜硝酸カルシウムの添加により増加して抢り、アルミネート相 㧍よびフェライト相の反応率は、亜硝酸カルシウムを添加しなかった試料と比較して 1.5 倍以上であった。 アルミネート相抄よびフェライト相の水和は、亜硝酸イオンを取り込んだ AFm 相扮よびエトリンガイ トの生成により初期に促進されたと考えた。
\end{abstract}

キーワード：亜硝酸カルシウム、アルミネート相、フェライト相、初期水和、 $\mathrm{AFm}$ 相、水和促進

\section{1. はじめに}

我が国では、COP21に扔いて温室効果ガスの排出量 を 2013 年比で $26 \%$ 削減することが 2030 年までに求め られて抢り ${ }^{1)} 、 2007$ 年度に扔いて我が国の $\mathrm{CO}_{2}$ 排出量 の 4 \%程度であるセメント産業に扔いても2)、 $\mathrm{CO}_{2}$ の削 減が求められる。この $\mathrm{CO}_{2}$ 削減の面㧍上び環境負荷低 減の面から考えた場合、混合セメントの利用は有効な方 法の一つである。このため、混合セメントの使用量は今 後増大するものと予想される。しかし、混合セメントは、 その初期強度が普通ポルトランドセメント (OPC) 上り 劣る傾向にあるため、この点を改善する必要がある。こ の改善を目的として、混合セメントの初期強度促進剤と しての亜硝酸カルシウムやトリイソプロパノールアミン を代表とするアルカノールアミン類の使用が検討 ${ }^{3}$. 4) れている。亜硝酸カルシウムの場合、コンクリートの硬 化促進剤の検討に扔いてフレッシュコンクリートのスラ ンプや空気量、硬化コンクリートの圧縮強度、長さ変 化、凍結融解抵抗性、鉄筋腐食性への影響例えば 5-7) や亜 硝酸カルシウムを添加した際の混合セメントの初期強度 の影響 8 について議論されているが、OPC の初期の水 和反応について言及したものは少ない。一方で我が国の コンクリートは、流動性抢よびその保持性能などの要求 性能を満足させる目的で減水剂や $\mathrm{AE}$ 剂などの化学混 和剂が広く利用されている。混合セメントの利用が拡大 した場合には、これら化学混和剤と初期強度促進剂を併 用することが考えられる。このような系ではセメント化 合物の水和反応はより複雑で多様なものとなると予想で きる。そのため、混和剤と促進剤の併用系での水和反応
について検討する前段階として、初期強度促進剤とセメ ント鉱物の水和反応について精査する必要がある。ま た、初期水和を考えた場合、間隙相の水和生成物である $\mathrm{AFm}$ 相は、電気的に負に帯電した陰イオンだけでなく 有機化合物もその層間に取り込むことが報告9)されてお り、間隙相、特にアルミネート相の初期水和に影響を与 えるものと考えられる。そこで本研究では、アルミネー 卜相とセッコウの水和生成物であるモノサルフェート水 和物 $\left(\mathrm{Ca}_{3} \mathrm{Al}_{2} \mathrm{O}_{6} \cdot \mathrm{CaSO}_{4} \cdot 12 \mathrm{H}_{2} \mathrm{O}\right.$ 、以下 $\left.\mathrm{AFm}\left(\mathrm{SO}_{4}\right)\right)$ に対し て亜硝酸カルシウムを添加した場合に打ける亜硝酸イオ ンと硫酸イオンのイオン交換反応について検討し、さら に亜硝酸カルシウムを添加した OPC の初期に扔ける水 和反応について、特に間隙相に着目し、検討することを 目的として検討を行った。

\section{2. 実験方法}

2. 1 モノサルフェート水和物と亜硝酸カルシウムの硫酸 イオン一亜硝酸イオンの陰イオン交換の検討

$\mathrm{AFm}\left(\mathrm{SO}_{4}\right)$ は文献 ${ }^{10)}$ を参考に合成を行った。水酸化 カルシウム、アルミン酸ナトリウム、硫酸ナトリウム (いずれも試薬特級)をモル比 $4: 1: 1$ で混合した粉体 試料を $50 \mathrm{~g}$ はかりとり、これに純水 $450 \mathrm{~mL}$ を添加し た。このサスペンション試料を $60{ }^{\circ} \mathrm{C} て ゙ 7$ 日間攪拌させ た。攪拌時には 1-ブタノールを数 $\mathrm{mL}$ 添加し、サスペ ンション試料の炭酸化防止とした。その後、試料をろ過 し、固相は多量のアセトンで洗浄した。その後、この固 相をアスピレータにより 24 時間 $\left(20{ }^{\circ} \mathrm{C} 、 6.6 \mathrm{kPa}\right)$ の条 件で減圧乾燥した。なお、乾燥後の試料は XRD により 
Table 1 Chemical composition and physical properties of ordinary Portland cement (OPC)

\begin{tabular}{|c|c|c|c|c|c|}
\hline \multicolumn{7}{|c|}{ Chemical composition (mass\%) } \\
\hline $\mathrm{CaO}$ & $\mathrm{SiO}_{2}$ & $\mathrm{Al}_{2} \mathrm{O}_{3}$ & $\mathrm{Fe}_{2} \mathrm{O}_{3}$ & $\mathrm{SO}_{3}$ & $\mathrm{MgO}$ \\
\hline 65.36 & 21.28 & 5.09 & 3.15 & 2.01 & 1.01 \\
\hline \multicolumn{7}{|c|}{ Mineral composition (mass \%) } & Density $\left(\mathrm{g} / \mathrm{cm}^{3}\right)$ & Fineness $\left(\mathrm{cm}^{2} / \mathrm{g}\right)$ \\
\hline $\mathrm{C}_{3} \mathrm{~S}$ & $\mathrm{C}_{2} \mathrm{~S}$ & $\mathrm{C}_{3} \mathrm{~A}$ & $\mathrm{C}_{4} \mathrm{AF}$ & 3.16 & 3,500 \\
\hline 60 & 16 & 8 & 10 & 3.16 & \\
\hline
\end{tabular}

$\mathrm{AFm}\left(\mathrm{SO}_{4}\right)$ 単相であることを確認した。

この合成した $\mathrm{AFm}\left(\mathrm{SO}_{4}\right)$ に対して質量比で 30 の割 合で水を添加し、サスペンション試料をつくった。この 試料に $\mathrm{AFm}\left(\mathrm{SO}_{4}\right)$ に対して 3.0、5.0、10 mass\%の亜硝 酸カルシウムを添加した。なお、亜硝酸カルシウムの添

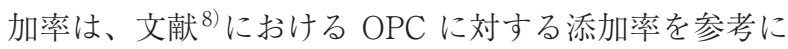
決定した。このサスペンション試料は 10 分間振り混ぜ た後に $20{ }^{\circ} \mathrm{C} の$ 条件で 7 日間静置保存した。所定期間終 了後の試料に対して、ろ過による固液分離をした。固相 は多量のアセトンを用いて洗浄し、さらにアスピレータ により 24 時間 $\left(20{ }^{\circ} \mathrm{C} 、 6.6 \mathrm{kPa}\right)$ の条件で減圧乾燥を行い、 各種の分析を行った。

\section{2. $2 \mathrm{OPC}$ の初期水和反応に及ぼす亜硝酸カルシウム の影響の検討}

OPC に対して外割で亜硝酸カルシウムを 3.0、5.0、 10 mass \% 添加したのち、水粉体質量比 $(\mathrm{W} / \mathrm{P}) 0.5$ の条 件で 10 分間練り混ぜた。その後、 $20{ }^{\circ} \mathrm{C}$ の室内にて所 定期間 (1、3、7、14、28days) 養生した。所定時間終了 後、水和試料に多量のアセトン中で粉砕し、その後、2.1 項の試料と同様にアスピレータにより 24 時間 $\left(20{ }^{\circ} \mathrm{C}\right.$ 、 $6.6 \mathrm{kPa})$ の条件で減圧乾燥を行った。この試料について、 XRD、TG-DTAによる測定を行った。なお、亜硝酸力 ルシウムの添加率は、2.1 項の検討と同様に、文献 ${ }^{8)}$ おける OPC に対する亜硝酸カルシウムの添加率を参考 に決定した。また、実験で使用した OPC (研究用セメン ト)の化学組成および鉱物組成は Table 1 に示した。

\section{3. 結果および考察}

\section{1 モノサルフェート水和物と亜硝酸カルシウム間の イオン交換反応に関する検討}

合成した $\mathrm{AFm}\left(\mathrm{SO}_{4}\right)$ に対して亚硝酸カルシウムを添 加し、水中で 7 日間反応させた試料の粉末 $\mathrm{X}$ 線回折 パターン結果を Fig. 1 に示す。亜硝酸カルシウムを無 添加の試料は、変化を示さず $\mathrm{AFm}\left(\mathrm{SO}_{4}\right)$ のピークのみ が確認できた。一方、亜硝酸カルシウムを 3.0、5.0、 $10 \mathrm{mass} \%$ 添加した試料では、いずれも $\mathrm{AFm}\left(\mathrm{SO}_{4}\right)$ の ピークが著しく減少した。そして、エトリンガイト $\left(\mathrm{Ca}_{3} \mathrm{Al}_{2} \mathrm{O}_{6} \cdot 3 \mathrm{CaSO}_{4} \cdot 32 \mathrm{H}_{2} \mathrm{O}\right)$ および車硝酸イオンを取 り込んた $\mathrm{AFm}$ 相 $\left(\mathrm{Ca}_{3} \mathrm{Al}_{2} \mathrm{O}_{6} \cdot \mathrm{Ca}\left(\mathrm{NO}_{2}\right)_{2} \cdot 10 \mathrm{H}_{2} \mathrm{O}\right.$ 、以下 $\left.\operatorname{AFm}\left(\mathrm{NO}_{2}\right)\right)$ が同定された。このため、 $\mathrm{AFm}\left(\mathrm{SO}_{4}\right)$ は、 層間の硫酸イオンと亜硝酸イオンとのイオン交換によ り $\operatorname{AFm}\left(\mathrm{NO}_{2}\right)$ を生成し、 $\mathrm{AFm}\left(\mathrm{SO}_{4}\right)$ の層間より追い出

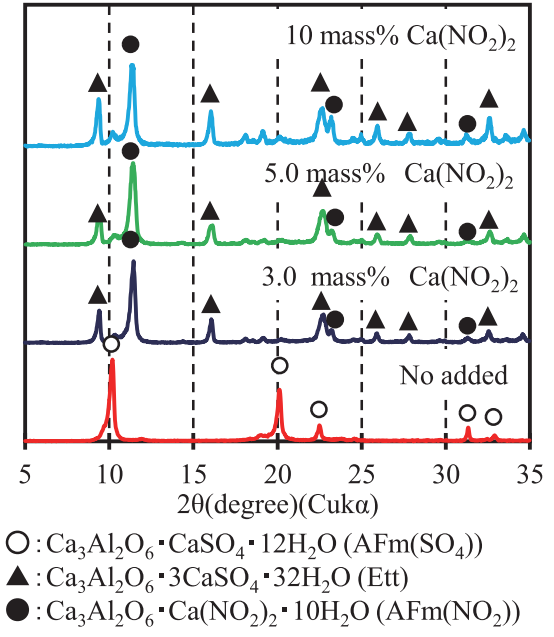

Fig. 1 XRD patterns of hydrate samples reacted from calcium aluminate mono-sulfate hydrates and calcium nitrite

された硫酸イオンと液相中のカルシウムイオンおよび 残存している $\mathrm{AFm}\left(\mathrm{SO}_{4}\right)$ からエトリンガイトを生成し たものと思われる。なお、本検討では $\mathrm{AFm}\left(\mathrm{SO}_{4}\right)$ に対 して亜硝酸カルシウムを 3.0、5.0、10mass\%添加した 条件では、 $\mathrm{AFm}\left(\mathrm{SO}_{4}\right)$ 中の $\mathrm{Al}$ に対して $2 \mathrm{NO}_{2}{ }^{-}$モル比 $\left(2 \mathrm{NO}_{2}{ }^{-} / \mathrm{Al}\right.$ モル比)でそれぞれ0.14、0.24、0.47 の

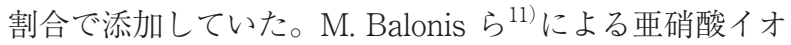
ンを層間に取り込んだ $\mathrm{AFm}$ 相の溶解度積データをも とに熱力学的安定性のシミュレーション結果では、系内 の $2 \mathrm{NO}_{2}^{-} / \mathrm{Al}$ モル比の増加に伴って $\mathrm{AFm}\left(\mathrm{SO}_{4}\right)$ の生 成量が減少する傾向を示し、一方でエトリンガイトおよ び $\mathrm{AFm}\left(\mathrm{NO}_{2}\right)$ の生成量が増加するとしている。本実験 結果でも、亚硝酸カルシウムの添加率の増加に伴ってエ トリンガイトのピーク面積が増加する傾向が確認できた ものの、系内の $2 \mathrm{NO}_{2}^{-} / \mathrm{Al}$ モル比の増加すなわち亜硝 酸カルシウムの添加率の増加に伴って、亜硝酸カルシウ ムの添加率 $3.0 \mathrm{mass} \%$ と少ない試料 $\left(2 \mathrm{NO}_{2}{ }^{-} / \mathrm{Al}\right.$ モル比 =0.14)においても $\mathrm{AFm}\left(\mathrm{SO}_{4}\right)$ のピークはほとんど確認 できず、この点について本報告と一致していない。この 結果の相違の理由は、水和生成物への硫酸イオンや覀硝 酸イオンの固溶(例えば $\mathrm{AFm}\left(\mathrm{NO}_{2}\right)$ への硫酸イオンの 固溶、 $\mathrm{AFm}\left(\mathrm{SO}_{4}\right)$ への亜硝酸イオンの固溶、エトリンガ イトへの硫酸イオンあるいは亜硝酸イオンの固溶)の可 能性が示唆される。このイオンの固溶に関しては、更な 
Table 2 Hydrated products added calcium nitrite to OPC detected by XRD

\begin{tabular}{|c|c|c|}
\hline & 7 days & 14 days \\
\hline No added & $\mathrm{CH}, \mathrm{C}-\mathrm{S}-\mathrm{H}, \mathrm{Ett}, \mathrm{AFm}\left(\mathrm{SO}_{4}\right)$ & $\mathrm{CH}, \mathrm{C}-\mathrm{S}-\mathrm{H}, \mathrm{AFm}\left(\mathrm{SO}_{4}\right)$ \\
\hline $\mathrm{Ca}\left(\mathrm{NO}_{2}\right)_{2} 3.0 \mathrm{mass} \%$ & $\mathrm{CH}, \mathrm{C}-\mathrm{S}-\mathrm{H}, \mathrm{Ett}, \mathrm{AFm}\left(\mathrm{NO}_{2}\right)$ \\
\hline $\mathrm{Ca}\left(\mathrm{NO}_{2}\right)_{2} 5.0 \mathrm{mass} \%$ & \\
\hline $\mathrm{Ca}\left(\mathrm{NO}_{2}\right)_{2} 10 \mathrm{mass} \%$ & \\
\hline
\end{tabular}

$\mathrm{CH}: \mathrm{Ca}(\mathrm{OH})_{2}, \mathrm{C}-\mathrm{S}-\mathrm{H}, \mathrm{AFm}\left(\mathrm{SO}_{4}\right): \mathrm{Ca}_{3} \mathrm{Al}_{2} \mathrm{O}_{6} \cdot \mathrm{CaSO}_{4} \cdot 12 \mathrm{H}_{2} \mathrm{O}$

Ett : $\mathrm{Ca}_{3} \mathrm{Al}_{2} \mathrm{O}_{6} \cdot 3 \mathrm{CaSO}_{4} \cdot 32 \mathrm{H}_{2} \mathrm{O}, \mathrm{AFm}\left(\mathrm{NO}_{2}\right): \mathrm{Ca}_{3} \mathrm{Al}_{2} \mathrm{O}_{6} \cdot \mathrm{Ca}\left(\mathrm{NO}_{2}\right)_{2} \cdot 10 \mathrm{H}_{2} \mathrm{O}$

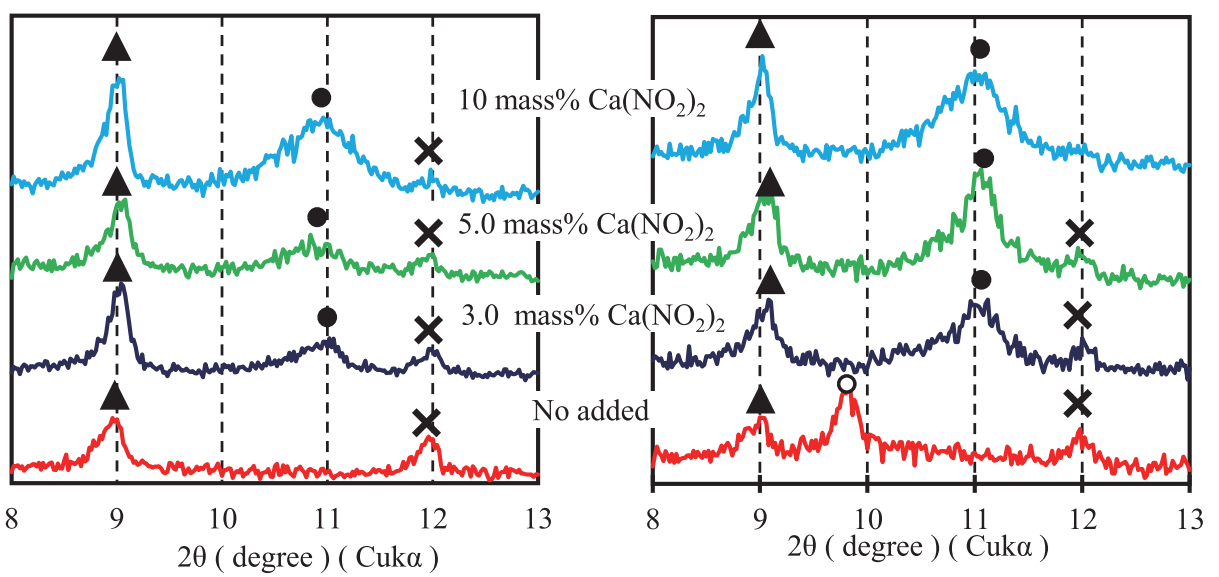

(a) 1 day

$\mathrm{O}: \mathrm{Ca}_{3} \mathrm{Al}_{2} \mathrm{O}_{6} \cdot \mathrm{CaSO}_{4} \cdot 12 \mathrm{H}_{2} \mathrm{O}\left(\mathrm{AFm}\left(\mathrm{SO}_{4}\right)\right)$

: $\mathrm{Ca}_{3} \mathrm{Al}_{2} \mathrm{O}_{6} \cdot \mathrm{Ca}\left(\mathrm{NO}_{2}\right)_{2} \cdot 10 \mathrm{H}_{2} \mathrm{O}\left(\mathrm{AFm}\left(\mathrm{NO}_{2}\right)\right)$ (b) 7 days

$\Delta: \mathrm{Ca}_{3} \mathrm{Al}_{2} \mathrm{O}_{6} \cdot 3 \mathrm{CaSO}_{4} \cdot 32 \mathrm{H}_{2} \mathrm{O}$ (Ett)

$\times: \mathrm{Ca}_{4} \mathrm{Al}_{2} \mathrm{Fe}_{2} \mathrm{O}_{10}\left(\mathrm{C}_{4} \mathrm{AF}\right)$

Fig. 2 XRD patterns of hydrate samples added calcium nitrite to OPC

(a) 1day, (b) 7days

る検討をすべきと考えられる。

\section{2 亜硝酸カルシウムを添加した OPC の水和反応}

$\mathrm{OPC}$ の水和生成物を XRD パターンより同定した生 成相を Table 2 に示す。亜硝酸カルシウムを無添加の 試料では、水和 7 日に拈いて水和生成物として水酸化 カルシウム、ケイ酸カルシウム水和物、 $\mathrm{AFm}\left(\mathrm{SO}_{4}\right)$ お よびエトリンガイトが、水和 14 日での水和生成物とし て水酸化カルシウム、ケイ酸カルシウム水和物および $\operatorname{AFm}\left(\mathrm{SO}_{4}\right)$ が同定された。一方、亜硝酸カルシウムを 添加した試料では、 $\mathrm{AFm}\left(\mathrm{SO}_{4}\right)$ はいずれの材齢におい ても確認されず、水酸化カルシウム、ケイ酸カルシウ 么水和物、 $\mathrm{AFm}\left(\mathrm{NO}_{2}\right)$ およびエトリンガイトが同定さ れた。また、Fig. 2 には水和 1 日および 7 日における $\mathrm{XRD}$ パターンのうち $2 \theta=8 \sim 13^{\circ}(\mathrm{CuK} \alpha$ 線使用)を示し た。この角度では、主に $\mathrm{AFm}$ 相やエトリンガイトな どの主要な回折ピークを確認することができる。亜硝酸 カルシウムを添加しなかった試料では、水和 1 日にお いて $\mathrm{AFm}\left(\mathrm{SO}_{4}\right)$ は確認できないが、亜硝酸カルシウム を添加した試料では $\mathrm{AFm}\left(\mathrm{NO}_{2}\right)$ のピークが確認でき、 また、添加率の増加に伴ってそれらのピークが大きくな る傾向を示した。さらに、エトリンガイトの生成も確認 できた。この傾向は、水和 7 日の回折ピークにおいて も同様であった。次に水和 1 日以内に拈りる水和反応
の違いを確認するため、亜硝酸カルシウムを添加時にお ける普通ポルトランドセメントの注水後 48 時間以内に おけるカロリーメータによる測定結果として、積算発 熱量を Fig. 3 に、水和発熱速度の変化を Fig. 4 に示す。 Fig. 3 では水和 24 時間以内の初期において、亜硝酸力 ルシウムを添加の試料では無添加の試料と比較して積算 発熱量が大きくなる傾向を示した。また亜硝酸カルシウ ムの添加率が 5.0 および 10 mass\%の試料の総発熱量は、 無添加の試料と比較して、水和 30 分および 6 時間程度 では 2.0 4.0 倍、水和 12 時間で $1.5 \sim 2.0$ 倍の值を 示しており、特に 24 時間以内の初期の水和反応が促進 していることがわかる。また、水和 48 時間経過時にお いても、亜硝酸カルシウムの添加試料の総発熱量は、無 添加の試料の総発熱量の 1.5 倍以上の值を示した。なお、 亜硝酸カルシウムの添加率が $5.0 \mathrm{mass} \%$ の試料の総発 熱量は、添加率が 3.0 mass \%の試料における総発熱量 と比較して、水和 48 時間までの範囲で大きくなる傾向 を示した。一方で添加率 10mass％の試料の総発熱量は、 添加率 $5.0 \mathrm{mass} \%$ の総発熱量と比較して水和 24 時間以 降で小さくなる傾向を示しており、これらより水和 48 時間における総発熱量は、覀硝酸カルシウムの添加率が 3.0 10mass \%の範囲内で、最も大きくなる添加率の最 適值が存在することが示唆される。 


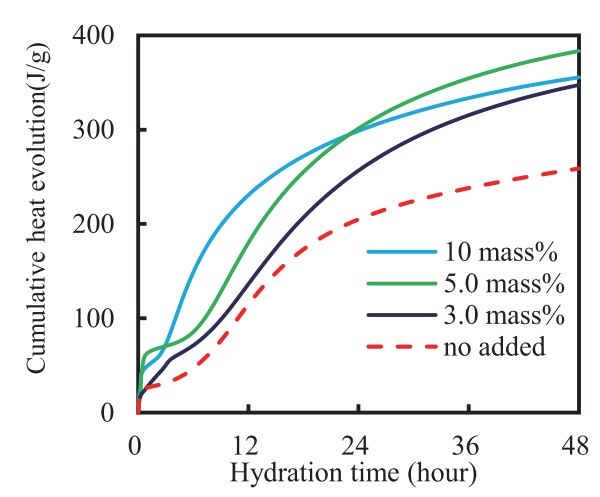

Fig. 3 Influence of $\mathrm{Ca}\left(\mathrm{NO}_{2}\right)_{2}$ on the cumulative heat evolution of OPC hydration

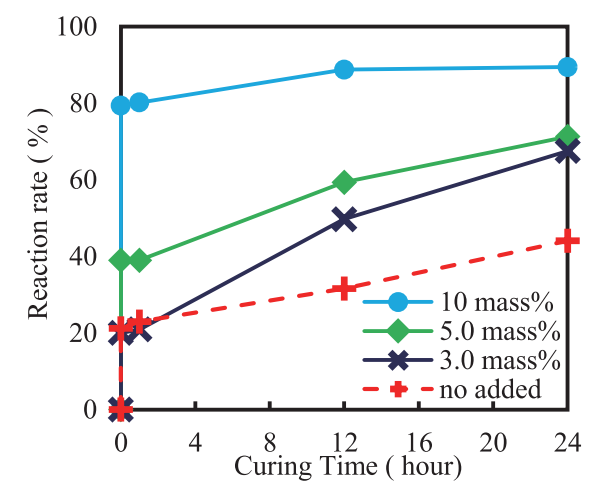

Fig. 5 Influence of $\mathrm{Ca}\left(\mathrm{NO}_{2}\right)_{2}$ of $\mathrm{C}_{3} \mathrm{~A}$ reaction rate in OPC detected by XRD

また、Fig. 4 の水和発熱速度の変化を比較すると、亜 硝酸カルシウム無添加の試料では水和 12 時間程度で水 和発熱速度のピーク值があらわれた。しかし、ピークの 位置が西硝酸カルシウムの添加率が $5.0 \mathrm{mass} \%$ では水 和 9 時間、添加率が $10 \mathrm{mass} \%$ では水和 5 時間程度と、 亜硝酸カルシウム添加率の増加に伴ってピークの現れる 時間がはやくなった。なお、亜硝酸カルシウムの添加率 が 3.0 mass\%のピークは水和 12 時間程度で亜硝酸カル シウムを添加しなかった試料と変わらないものの、水和 4 時間までに発熱速度のピークが現れており、亜硝酸力 ルシウムの添加により注水後 12 時間程度の水和反応が 促進されていることが確認できる。

そこで、亜硝酸カルシウムの添加により特に 1 日以 内の水和反応を確認する目的で、OPC 中のアルミネー 卜相の反応率の変化を Fig. 5 に、フェライト相の反応 率の変化を Fig. 6 に示す。アルミネート相の反応率は、 水和時間が 12 時間で亜硝酸カルシウムの添加に伴っ て、無添加試料と比較して大きくなる傾向を示した。特 に $5.0 \mathrm{mass} \%$ 以上の亜硝酸カルシウムを添加した試料 ではその傾向が顕著で、水和 30 分の段階で添加率が 10mass\%の試料における反応率が 80 \%と大きな值を示 し、添加率が 5.0 mass \% の試料でも反応率が $40 \%$ と、 亜硝酸カルシウムを無添加の試料における反応率の約 2

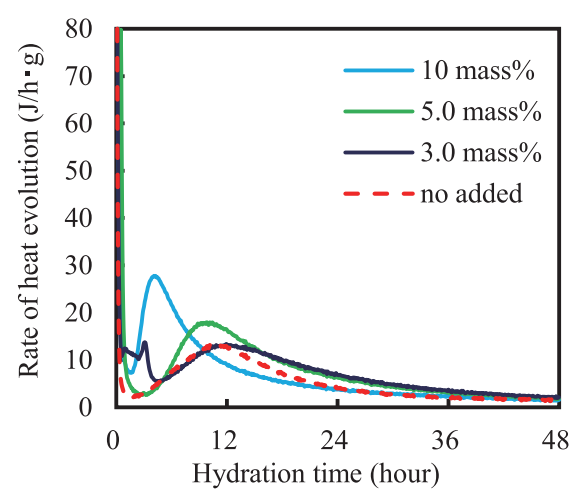

Fig. 4 Influence of $\mathrm{Ca}\left(\mathrm{NO}_{2}\right)_{2}$ on rate of heat evolution of OPC hydration

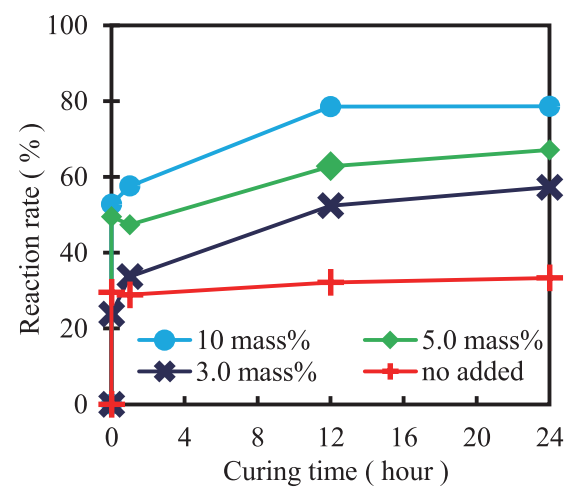

Fig. 6 Influence of $\mathrm{Ca}\left(\mathrm{NO}_{2}\right)_{2}$ of $\mathrm{C}_{4} \mathrm{AF}$ reaction rate in OPC detected by XRD

倍を示した。

また、フェライト相もアルミネート相と同様に亜硝酸 カルシウム無添加の試料と比較してその反応率が増加す る傾向を示した。水和 30 分において、亜硝酸カルシウ ムの添加率が 5.0 mass \% 以上の試料では反応率が $50 \%$ 程度であった。なお、亜硝酸カルシウム $3.0 \mathrm{mass} \%$ 添 加した試料では、水和 30 分においては亜硝酸カルシウ 厶無添加の試料と同程度の反応率であったものの、水和 12 時間では 50 \%程度と、亜硝酸カルシウムを無添加の 試料ではフェライト相の反応率が 30 \%であったことと 比較して 1.5 倍以上の值となった。これらのことから、 亜硝酸カルシウムの添加によって水和 1 日以内の初期 材齢に拈いて、OPC 中のアルミネート相およびフェラ イト相の水和反応の促進が確認された。

次に亜硝酸カルシウムを添加した OPC 中のアルミ ネート相およびフェライト相の 1 日以内の初期の水和 反応メカニズムについてさらに考察を加える。姜ら ${ }^{12)}$ は、アルミネート相の初期水和の反応についてアルミ ネート相の表面にセッコウより供給される硫酸イオンが 供給されて生成したゲル状水和物 $\left(\mathrm{Ca}_{3} \mathrm{Al}_{2} \mathrm{O}_{6} \cdot \mathrm{mCaSO}_{4}\right.$ ・ $\left.\mathrm{nCaO} \cdot \mathrm{xH}_{2} \mathrm{O}\right)$ によって制御されるとしている。このゲル 状水和物中の $\mathrm{m}$ の值が大きい場合、ゲル状水和物の物 質透過性が低く、このためアルミネート相の溶解反応が 

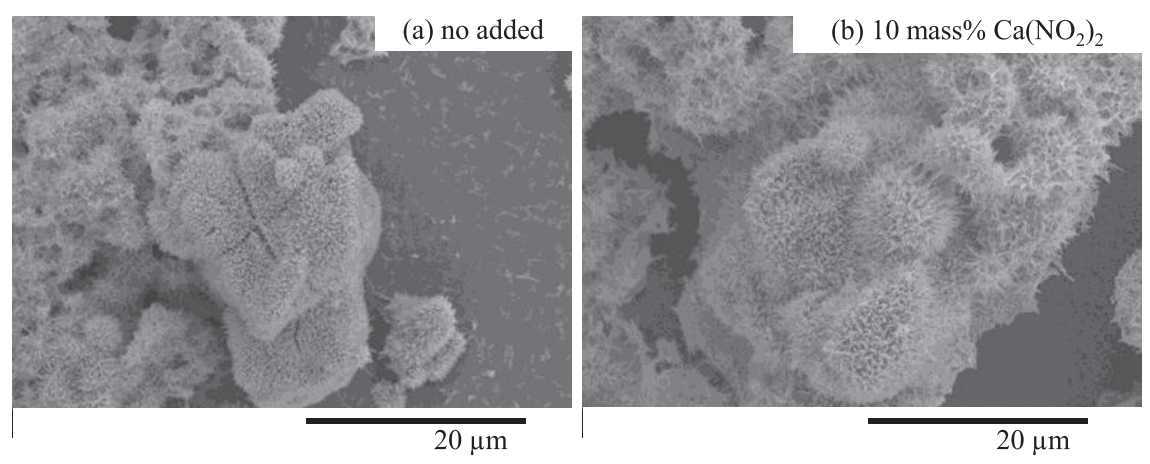

Photo. 1 SEM images of $\mathrm{C}_{3} \mathrm{~A}$-gypsum samples hydrated for 30 minutes

(a) No added, (b) 10 mass $\% \mathrm{Ca}\left(\mathrm{NO}_{2}\right)_{2}$

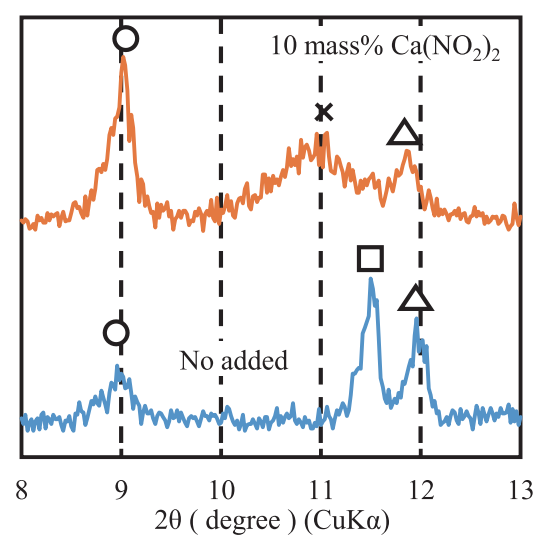

$\mathrm{O}: \mathrm{Ca}_{3} \mathrm{Al}_{2} \mathrm{O}_{6} \cdot 3 \mathrm{CaSO}_{4} \cdot 32 \mathrm{H}_{2} \mathrm{O}, \mathrm{Ett}$

$\times: \mathrm{Ca}_{3} \mathrm{Al}_{2} \mathrm{O}_{6} \cdot \mathrm{Ca}\left(\mathrm{NO}_{2}\right)_{2} \cdot 10 \mathrm{H}_{2} \mathrm{O}, \mathrm{AFm}\left(\mathrm{NO}_{2}\right)$

$\square: \mathrm{CaSO}_{4} \cdot 2 \mathrm{H}_{2} \mathrm{O}$, gypsum

$\triangle: \mathrm{Ca}_{4} \mathrm{Al}_{2} \mathrm{Fe}_{2} \mathrm{O}_{10}, \mathrm{C}_{4} \mathrm{AF}$

Fig. 7 XRD patterns of $\mathrm{C}_{3} \mathrm{~A}$-gypsum samples hydrated for 30 minutes

抑制され、一方、 $\mathrm{m}$ の值が小さいゲル状水和物が生成 した場合にはアルミネート相の溶解反応が促進されると している。このため亜硝酸カルシウムを添加では、明ら かにアルミネート相の水和反応が促進しており、前述の ゲル状水和物が形成されない、あるいは別の物質透過性 の高い水和物の生成が疑われる。そこで、亜硝酸カルシ ウムを無添加および 10mass\%添加したアルミネート相 -2 水セッコウ系の試料の水和 30 分における組織観察し た写真を Photo. 1( (a) : 严硝酸カルシウム無添加、(b) : 10mass\%亜硝酸カルシウム添加)に示す。両写真におい て表面にエトリンガイトと思われる針状結晶によって未 反応の間隙相の粒子の表面の大部分が覆われており、亜 硝酸カルシウムの添加の有無による違いがほとんど無い ように見受けられる。そこで、さらに検討を加えるため、 水和 30 分における水和試料の XRD パターン $(\mathrm{CuK} \alpha$ 線、 $2 \theta=8 \sim 13^{\circ}$ )を Fig. 7 に示す。亜硝酸カルシウムの 添加の有無にかかわらず、Fig. 7 ではエトリンガイトの ピークが同定された。一方、亜硝酸カルシウムを無添 加の試料では 2 水セッコウの残存が確認されたものの、 $\mathrm{AFm}\left(\mathrm{SO}_{4}\right)$ 等の $\mathrm{AFm}$ 相は同定されなかった。一方、亜
硝酸カルシウムを添加した系では、2 水セッコウのピー クは消失しており、 $\mathrm{AFm}\left(\mathrm{NO}_{2}\right)$ のピークが同定された。 Photo. 1 の組織の表面観察をもとに考えると、亜硝酸力 ルシウムを添加した場合、未反応の粒子表面の大部分が エトリンガイトに覆われており、両試料ともに水和反応 が抑制されるものと予想される。しかし、亜硝酸カルシ ウムを添加した試料では水和反応が促進されていた。2 つの試料の違いは、亜硝酸カルシウムを添加した試料で は $\mathrm{AFm}\left(\mathrm{NO}_{2}\right)$ が生成した点である。これらの系におけ る水和生成物の溶解度積を考えた場合、M. Balonis らは $\mathrm{AFm}\left(\mathrm{NO}_{2}\right)$ の $25^{\circ} \mathrm{C}$ における logKso はー26.24 ${ }^{9)}$ として おり、この值はエトリンガイト $(-44.9)^{13)}$ や $\mathrm{AFm}\left(\mathrm{SO}_{4}\right)$ $(-29.26)^{13)}$ の $\log \mathrm{Kso}$ と比較すると小さい。このため、 $\mathrm{AFm}\left(\mathrm{NO}_{2}\right)$ はエトリンガイトや $\mathrm{AFm}\left(\mathrm{SO}_{4}\right)$ と比較して 物質透過性が高い水和物であるといえる。これらのこと から、亜硝酸カルシウムを添加した試料においては、未 反応の粒子の周囲にエトリンガイト系水和物とともに物 質透過性の高い $\mathrm{AFm}\left(\mathrm{NO}_{2}\right)$ が一部生成しており、この ためアルミネート相やフェライト相の水和反応が促進し たのではないかと考えられる。

\section{4. まとめ}

モノサルフェート水和物に対して亜硝酸カルシウムを 添加した場合における亜硝酸イオンと硫酸イオンのイオ ン交換反応および亜硝酸カルシウムを添加した普通ポル トランドセメント $(\mathrm{OPC})$ の初期の水和反応について検 討した結果、以下の結論を得られた。

1）モノサルフェート水和物に対して亜硝酸カルシウム を添加した場合、亜硝酸イオンと硫酸イオンがイ オン交換することでエトリンガイトの生成および $\mathrm{AFm}\left(\mathrm{NO}_{2}\right)$ の生成が確認された。

2）亜硝酸カルシウムを添加した普通ポルトランドセメ ント系では、水和 1 日以内の初期において間隙相(ア ルミネート相およびフェライト相)の反応率の増加 が確認された。

3）普通ポルトランドセメントに亜硝酸カルシウムを添 加した場合、水和 30 分に関わらずエトリンガイト および $\mathrm{AFm}\left(\mathrm{NO}_{2}\right)$ の生成が確認された。 


\section{謝辞：}

本研究デー夕をとりまとめるにあたり、島根大学大学 院総合理工学研究科の宋玄眞氏に多大なご協力をいただ きました。ここに記して謝意を示します。

\section{参考文献：}

1）全国地球温暖化防止活動推進センター<世界の動向 (COP 等)、COP 等(国際会議) レポート、第 21 回 締約国会議 $(\mathrm{COP} 21)>$

http://www.jccca.org/trend_world/conference_ report/cop21/

2）細谷俊夫：セメント産業に抢ける $\mathrm{CO}_{2}$ 排出削減 の取り組み、コンクリート工学、Vol. 48、No. 9、 pp. 51-53 (2010)

3）大西雄大ほか：セメントの初期水和反応に及ぼすア ルカノールアミンの影響、第 71 回セメント技術大 会講演要旨、pp. 58-59 (2017)

4）坂井悦郎ほか：亜硝酸カルシウムを添加した高炉ス ラグ高含有セメントの水和、第 71 回セメント技術 大会要旨、pp. 92-93 (2017)

5）高谷哲ほか：コンクリート中に扔ける亜硝酸イオン の鋼材腐食抑制メカニズム、コンクリート工学年次 論文集、Vol. 36、No. 1、pp. 1270-1275（2014）

6）西晴哉ほか：硬化促進剤を用いた高強度コンクリー トの研究、セメント技術年報、28、pp. 256-259（1974）

7）黒田武ほか：無塩素·無アルカリ金属系硬化促進剤、 セメント技術年報、40、pp. 226-228（1986）

8）坂井悦郎ほか：亜硝酸カルシウムを添加した高炉久 ラグ含有セメントの水和、セメント・コンクリート 論文集、Vol. 71、pp. 62-67（2017）

9) S. Stober et al. : Synthesis of a lamellar calcium aluminate hydrate (AFm phase) containing benzenesulfonic acid ions, Cement \& Concrete Research, Vol. 29, pp. 1841-1845 (1999)

10）一般社団法人セメント協会：セメント・コンクリー 卜化学 解説付きデー夕集、p. 352-353（2016）

11) M. Balonis et al. : Influence of calcium nitrate and nitrite on the constitution of $\mathrm{AFm}$ and $\mathrm{AFt}$ cement hydrates. Advanced in Cement Research, Vol. 23, pp. 129-143 (2011)

12）姜珍圭ほか: $\mathrm{Ca}_{3} \mathrm{Al}_{2} \mathrm{O}_{6}-\mathrm{CaSO}_{4} \cdot 2 \mathrm{H}_{2} \mathrm{O}-\mathrm{CaO}$ 系の水 和反応に及ぼす分散剂の影響、セメント・コンクリー 卜論文集、No. 54、pp. 22-27（2000）

13) B. Lothenbach et al. : Thermodynamic modelling of the effect of temperature on the hydration and porosity of Portland cement, Cement \& Concrete Research, Vol. 38, pp. 1-18 (2008) 


\title{
INFLUENCE OF CALCIUM NITRITE ON THE EARLY- HYDRATION OF ALUMINATE AND FERRITE PHASE IN ORDINARY PORTLAND CEMENT
}

\author{
Junichi OHYA ${ }^{* 1}$, Daiki ATARASHI², Hirotaka HARA ${ }^{* 3}$ and Yuji SUDO ${ }^{* 4}$
}

*1 NiHON UNIVERSITY, College of Science \& Technology (7-24-1, Narashinodai, Funabasi-shi, Chiba 274-8501, Japan)

*2 SHIMANE UNIVERSITY, Graduate School of Natural Science and Technology (1060, Nishikawadu-cho, Matsue-shi, Shimane 690-8504, Japan)

*3 KYUSHU UNIVERSITY, Interdisciplinary Graduate School of Engineering Sciences (6-1, Kasugakoen, Kasuga-shi, Fukuoka 816-8580, Japan)

*4 NISSAN CHEMICAL INDUSTRIES, LDC., Chemicals (3-7-1, Kanda-Nishiki-cho, Chiyoda-ku, Tokyo 101-0054, Japan)

\begin{abstract}
This paper discusses the influence of calcium nitrite on the early hydration reaction of the Ordinary Portland Cement (OPC). The AFm phase containing nitrite ion $\left(\mathrm{AFm}\left(\mathrm{NO}_{2}\right), \mathrm{Ca}_{3} \mathrm{Al}_{2} \mathrm{O}_{6}\right.$. $\left.\mathrm{Ca}\left(\mathrm{NO}_{2}\right)_{2} \cdot 10 \mathrm{H}_{2} \mathrm{O}\right)$ and ettringite $\left(\mathrm{Ca}_{3} \mathrm{Al}_{2} \mathrm{O}_{6} \cdot 3 \mathrm{CaSO}_{4} \cdot 32 \mathrm{H}_{2} \mathrm{O}\right)$ are formed after 1-day hydration time. Even after 30-minute hydration time, these hydrated products are formed. Also, these are remained in the 14-day samples without changing the other hydrations. By adding calcium nitrite, the amount of cumulative heat evolution of OPC increases after 48 hours. In this 48 hours, the reaction rates of aluminate phase $\left(\mathrm{Ca}_{3} \mathrm{Al}_{2} \mathrm{O}_{6}\right)$ and ferrite phase $\left(\mathrm{Ca}_{4} \mathrm{Al}_{2} \mathrm{Fe}_{2} \mathrm{O}_{10}\right)$ in the OPC mixed with calcium nitrite are more than 1.5 times larger than those without calcium nitrite. When calcium nitrite is added to aluminum phase and gypsum and hydrated for 30 minutes, hydrated products are observed around the unreacted grains by SEM photograph. We considered that the accelerations of the aluminate phase and the ferrite phase in the OPC are related to the formation of those hydrations. Adding calcium nitrite to the OPC accelerates the reactions of the aluminate phase and that of ferrite phase in the OPC during the early stages of hydration.
\end{abstract}

KEY WORDS : Calcium nitrite, Aluminate, Ferrite, Early hydration, AFm phases, Hydration accelerator 